\title{
Entrevista com Roberto Menescal
}

JULIANA RIPKE

Universidade de São Paulo (juripke@hotmail.com)

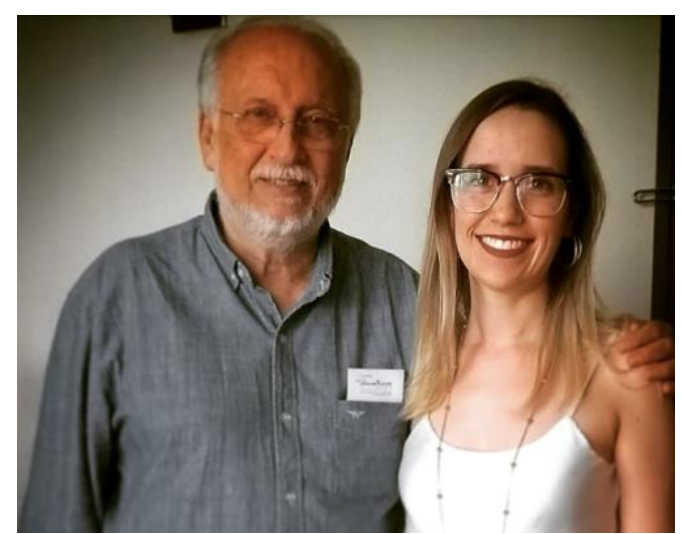

Foto: Roberto Menescal e Juliana Ripke.

\section{Apresentação}

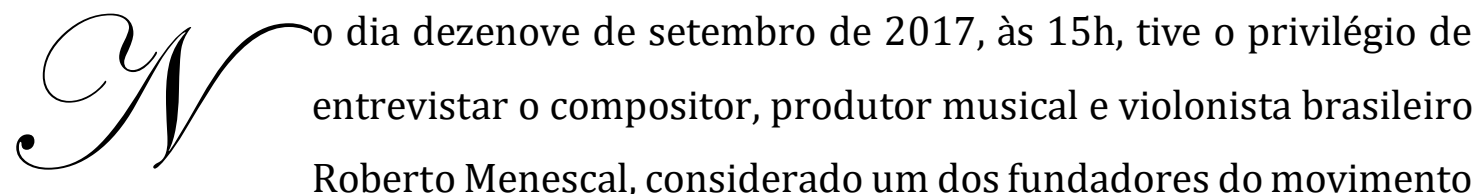
da Bossa Nova, autor da famosa canção $O$ barquinho, dentre inúmeras outras. Desde o primeiro contato que fiz com ele, primeiramente via telefone e depois via e-mail, foi extremamente prestativo e gentil. A intenção era entrevistá-lo sobre sua história, sua carreira, sua presença na música brasileira, as histórias da Bossa Nova e suas relações com músicos atuantes da época, dentre eles Tom Jobim, João Gilberto e Villa-Lobos.

Após algumas trocas de mensagens, marcamos a entrevista para um dia que Menescal estaria em turnê de shows por São Paulo. Desde o primeiro contato pessoalmente a conversa foi se desenvolvendo informalmente, quando então ele começou a falar sobre sua relação com Tom Jobim. Percebendo sua boa disposição para falar sobre o assunto, rapidamente liguei o gravador para registrar seu relato, que começou assim:

ROBERTO MENESCAL: Meus irmãos são arquitetos, 3 irmãos. Meu pai é engenheiro, e eu queria ser músico, mas não achava como começar. Eu queria conhecer muito Tom Jobim, e passei um ano tentando. Me diziam: "O Tom vai na 
casa de não sei quem", e lá ia eu, era o primeiro a chegar na casa. Nesse tempo se bebia muito Cuba Libre, que era rum com Coca Cola. E eu tomava os Cuba Libre todos.

Então eu ia à procura do Tom Jobim nos lugares que falavam que ele iria. Eu chegava lá, e quando ele chegava eu tinha já tinha sido levado embora, completamente bêbado, né? [risos]. Eu não era de beber não, mas ficava excitado com aquilo... E passou um ano assim. Eu dizia: "De repente não era pra conhecer Tom Jobim, né?".

Eu dava aula, eu e o Carlinhos Lyra, pras meninas todas da época, porque todas elas queriam tocar violão, batidinha da Bossa Nova. Aí um dia de seis horas da tarde toca a campainha, eu abro a porta (a gente atendia, a gente servia café, a gente fazia tudo): Tom Jobim. Ah! [suspiro e expressão de espanto]. Ele falou: "Menescal? Cê tá ocupado?”. Eu com o violão: “Não, não, não tô não!”. "Você não taí dando aula pra menina?". "Não, não, não". "Pois é, eu vou gravar a trilha do filme Orfeu do Carnaval e me falaram que você podia fazer isso, o tipo de coisa que eu quero". "Claro que eu posso". "Mas não vai te atrapalhar...?". "Não...". Fui lá na menina e falei: "Dez aulas de graça" e tal, e fomos [risos].

Bom, eu ia fazer vestibular, ia fazer pro exame do Banco do Brasil e pra Marinha. Aí o Tom, no final, me chamou no canto e falou: "Vamos acertar aqui o teu cachê". "Cachê de quê?". "Do filme, de tocar no filme... quanto eu te devo?" [risos]. “Imagina se eu vou...”. “Não, não”. E eu disse: “Não, não aceito, eu não posso aceitar, vai por mim que eu não posso aceitar". E ele falou: "Então vamos jantar". Fomos jantar, sentamos na mesa, e ele falou: "Bom, que que você está fazendo?". "Eu estou dando umas aulinhas de violão e tal, e fazendo vestibular disso...", e ele falou: "Mas por que você está fazendo? Você não quer ser músico?". Eu disse: “Quero”. "Então larga essas e vai ser músico...”. Né? Simples, né, a coisa?

Aí cheguei em casa [risos], cheio de coragem, e falei. Meu pai não entendeu, não entendeu, meus irmãos também ficaram assim, e tal. Bom, pouco depois meu pai faleceu. Ele deixou um diário, e a gente descobriu esse diário que eu não sabia que ele escrevia todo dia. 0 diário era eu, né? "Meus filhos, cuidem do Beto, coitado, vai ser músico... Não, deixa ele, não sei o quê, coitado... Ele vai morrer de fome...”. E o diário inteiro assim. Eu fiquei muito traumatizado com aquilo, foi um sofrimento 
que meu pai teve e nunca falou isso comigo, né? E eu já tinha umas músicas tocando no rádio e tal. Um dia até estava no telefone... Era uma sala grande que a gente tinha... Na cadeira de balanço, ficava olhando assim [balança a cadeira], do lado do som. Aí a gente tocou uma música, e falou assim: "Acabamos de ouvir, com Maysa, Nós e o mar de Menescal e Bôscoli". Ele parou a cadeira e ficou, daqui a pouco voltou e não falou nada [risos]. Aí depois perguntou pra minha mãe: "Vem cá, aquele Menescal é o Roberto?”. Ela falou: "É, é”. “Ah, tá”. E pronto, mas nunca falamos sobre isso.

Bom, meu irmão foi agora, cinquenta anos depois, lá em casa e falou: “Beto, encontrei aquele diário do pai, você quer ler?”. “Não...”. É que eu me lembro que aquilo me mexeu muito, né? "Não, mas olha, seria legal, cinquenta anos depois, você tem que ler!". E legal se pai tivesse vendo essa trajetória toda, de repente hoje ele falaria assim: "Beto, cuida dos seus irmãos que foram ser arquitetos, coitados, né? [risos]. Não deixa eles morrerem de fome". Porque a arquitetura passou por um processo muito radical. Quer dizer, me lembro no escritório do meu irmão, eram 22 caras com aquelas pranchetas enormes, um salão, e todo mundo ali [gestos como se estivesse desenhando]. Hoje você vê o cara no computador, vira a casa do outro lado, vira não sei o quê, e meus irmãos não chegaram a acompanhar isso. Mas ficaram na deles, entende? Estão bem, está tudo bem, mas... Pararam, né? Eu graças a Deus estou na música até hoje, porque a gente foi mudando junto, né?

JULIANA RIPKE: É que a música hoje também se profissionalizou mais, não é?

RM: Muito! É, poxa, meu pai ficou assim porque nós tínhamos ido comer pizza, (a primeira vez que eu comi pizza na minha vida) num restaurante lá no Rio, e vieram três velhinhas jantar, botaram as coisas no chão e tocaram. Aí a gente deu dinheiro, e ele falou: "É isso que você quer? Você quer tocar lá na porta do restaurante?". "Não pai, não é isso...". Mas eu não sabia dizer também...

JR: Bom, vou começar com uma pergunta básica, que você já deve ter ouvido muito. Você já falou um pouquinho sobre a sua relação com Tom Jobim... Mas, pra 
você, o que a Bossa Nova representou na música brasileira? Qual o papel dela na música brasileira?

RM: Eu acho que ela fez uma passagem muito importante, porque... Eu vou dizer: antes da Bossa Nova, você tinha baião, tinha samba, né? Mas o samba-canção dominava. Melodias maravilhosas que tinham. Eu adorava samba-canção, mas as letras eram danadas, e gente tinha dezoito anos, nós fomos os primeiros a usar bermudas no Brasil [risos]. Imagina, dezoito anos: "Se eu morresse amanhã de manhã não faria falta a ninguém..." [cantando]. Não podia... As letras eram todas assim. "Sei que falam de mim, sei que zombam de mim, óh Deus como eu sou infeliz..." [cantando]. Todas! Não tinha uma feliz, uma. Eu acho que é um pouco pela época. Você trabalhava o dia inteiro numa firma, de noite trabalhava numa boate, aí enchia a cara... A infelicidade aparecia ali, pela vida que você estava levando. E nós gostávamos, mas ao mesmo tempo falávamos: “Cara, a gente não pode estar tocando essas músicas...". E começamos a brincar de fazer música. 0 que a gente ouvia mesmo era jazz, né? Noites e noites com aqueles discos, sabe, até madrugada, e a gente tentando tirar as coisas... Mas lembrando o seguinte, as gravações eram feitas em um canal, então você tinha a orquestra de quarenta e quatro figuras, uma cantora e um vocal, tudo em um canal.

JR: Não podia errar, não é?

RM: Não podia. E ainda os caras no final falavam: “Alguém errou? Não? Então tá...”.

Bom, com isso você não distingue o que o piano faz direito. Era baixo, bateria, guitarra, piano [imita os sons, como que tocando os instrumentos]. Mas você, na verdade, não tinha exatamente como saber o que era um acorde. E a gente procurava, a gente falava assim: “A gente sabe uns acordes modernos, né?”. Uns acordes lá que não era nada de muito demais, mas já era um pouco na frente do que se fazia, porque a gente tirava muito de jazz. Até que um dia apareceu um disco chamado Julie is her name: a cantora Julie London, com um guitarrista, Barney Kessel, e um baixista, Ray não sei o quê. 0 primeiro acorde que o cara deu: "Pom plim clim clim clom..." [imitando tocar guitarra], eu ouvi todas as notas, porque era 
só guitarra só fazendo. Eu disse: "Que que é isso?". Botei novamente: "Plim plim" [imita tocando violão], era uma música, Cry me a river. E ela cantando muito bem. Aquele disco, quando eu ouvi aquilo eu falei: “Opa, tem uma coisa aqui que mudou o mundo". Aí chamei tudo quanto era violonista que eu conhecia: Baden Powell, Oscar Castro Neves, Carlos Lyra, todo mundo. Reuni e falei: "Vamos ouvir um disco aqui" [cara de espanto]. Todo mundo assim: “Ok!”. Todo mundo ficou espantado. “Aqui está o segredo da nova música. Cada um vai tirar uma música, daqui há um mês a gente se encontra..." [risos]. Aí cada um veio com o que conseguiu tirar. Você não conseguia tudo, mas porque não tocava, não tinha aqueles acordes, não tinha internet. Então ficou um negócio assim: a gente se encontrava todo dia, e tocando... E aí já sugeria uma música nova aquele acorde. Eu tenho, na minha cabeça: a música brasileira andou dez anos em um ano, dez anos, e não é modo de falar. Você vê que dali as músicas começaram a ficar bem mais modernas do que eram.

JR: Que ano foi isso?

RM: Foi cinquenta e... a gente até brinca... mil novecentos e Aracy de Almeida... [risos]. Foi, eu te digo: eu tinha dezenove anos. Sabe, a gente ali, garoto ainda, tentando tirar, tentando aquelas coisas todas, e cada dia saía um. E aí foi ficando o negócio da modernidade, só se pensava em moderno. Chegou um ponto tão absurdo que eu me lembro de um cara chamado Mário Castro Neves, que era um pianista muito bom, irmão do Oscar Castro Neves, ele fez uma música e falou assim pra mim [fingindo tocar piano]: "Essa ninguém canta...", e eu falei assim: "Mas qual a vantagem? [risos], qual a vantagem de ninguém cantar?". E ele ficou meio assim, sabe: "É mesmo...". Quer dizer, você procurava aquilo ali sem pensar muito no que ficava, e se as pessoas podiam acompanhar. Mas aí veio uma legião de artistas conhecidos, Lúcio Alves, Dick Farney, e falaram: "Pô, bacana, como é que é isso aí?". Então a gente começou a ficar meio conhecido ali, sabe. Por isso que eu te digo: a Bossa Nova trouxe essa coisa da harmonia, principalmente da harmonia, e por consequência as melodias. Tinha música minha que eu toco hoje pra você, e você fala: "Pô, bacana e tal”, e na época era: “Como é que foi? Você foi pra onde? Que isso?". Era tão diferente, hoje é tão normal. Eu ensaiei duas músicas agora que o pessoal 
não conhecia: “Ah, bacana e tal...” Acabou-se. Na época, falavam: “Não, pô, errou, você errou aqui". Não tem erro, né? Apenas não se usava.

JR: Mas essa harmonia veio do jazz, então?

RM: Veio, as harmonias vieram realmente do jazz. Bom, as melodias vieram como decorrência da harmonia, e as letras. Porque aí teve uma combinação nossa. Cara, a gente tinha dezoito anos, dezenove anos, vintes anos, a gente tinha que cantar. A gente morava em frente à praia, né? Nós todos morávamos em Copacabana. Nara Leão morava em um apartamento com quinze metros de janela pro mar, e você sentado não via o trânsito, via só o mar [sorriso]. Então, era o nosso mar! Como você vai dizer: "Ninguém me ama, ninguém me quer"? Aí começamos: "Vamos cantar a esperança, vamos cantar a coisa bonita da vida, a felicidade”. E aí foi mudando, sabe? Você começa a ver... Até tem uma música bonita do Jobim que eu ponho como ponto de virada, de partida. A gente fez coisa antes mas, quando você ouve Chega de Saudade: "Vai, minha tristeza...". É samba-choro, samba-canção: "Diz a ela que sem 244 ela não pode ser" [cantando]. Aí quando entra na segunda parte é maior: "Mas se ela voltar, se ela voltar...”. Então acho que ali... Ôpa! [sinal das mãos e braços se abrindo], virou o mundo, né? Abriu!

Então, acho que a Bossa Nova foi muito importante pra música brasileira. Só que o seguinte, era uma classe média privilegiada que curtia. Era o pessoal da zona sul. A gente não sabia nem o que acontecia na zona norte, não tinha túnel, então levava quatro horas até a zona norte. Depois você vê a classe média baixa e a classe $C$ principalmente, que não tinham condições de ir a show, de comprar disco. Essa se fortaleceu. De quinze, vinte anos pra cá, começou a comprar disco e ir a show. Então começou a virar a verdadeira música popular brasileira. É essa que está agora, não tem dúvida. A gente tinha tanta certeza que colocou: MPB! Nada, que MPB, MCB: Música Criativa Brasileira [risos]. Mas não era. Agora, qual era o público que via a gente, que ia aos shows e tudo. Era a MPB da gente!

Mas a música brasileira mudou totalmente, cresceu muito. 0 choro voltou e voltou fera. As pessoas aí fazendo choro hoje da até medo. Então foi isso. E é o 
seguinte, ela voltou pro jazz, voltou pra lá. 0 jazz abraçou a nossa música e falou: "Ôpa".

JR: 0 ritmo da Bossa Nova veio, então, da música brasileira?

RM: Veio da música brasileira!

JR: E o violão do João Gilberto?

RM: É, o violão do João acho que definiu a coisa que todos procuravam. Porque nada muda de hoje pra amanhã. Eu tinha uma batida, eu não sabia tocar samba. Então eu tinha uma batida pra tocar o samba, Carlinhos Lyra tinha outra, Oscar Castro Neves tinha outra. Aí o Baden era mais samba. Muito parecidas elas. Aí quando chegou a do João Gilberto eu disse: “Ah, essa que eu queria”. Porque o João Gilberto fez uma coisa muito inteligente, ele queria tocar o samba mas falou: “0 samba tem bumbo, ganzá, agogô, reco-reco, tudo, tamborine...". Ele falou: “O que eu posso pegar daí que é meio síntese da coisa?". E ele pegou o tamborim [imita o ritmo do tamborim]. Só isso... E falou: "Eu não posso botar tudo, né?". Aí facilitou tudo pra gente, e pro exterior. Os caras no exterior ficaram loucos. Quando a gente esteve lá em 1962, que foi a primeira ida da gente, aqueles músicos que a gente amava, amava, sabe? E que nunca iríamos encontrar um caras desses, mas sabíamos tudo da vida dele... Quando a gente chegou no aeroporto estavam todos esperando a gente. Eu ainda, idiota aqui, falei: “Turma (não tinha galera ainda, né?)... Turma, olha que sorte a gente chegando aqui...". Aí o cara que estava recebendo a gente falou assim: "Não, eles não estão aqui por acaso não, eles vieram receber vocês".

JR: Quem era?

RM: Gerry Mulligan, Cannonball Adderley, Modern Jazz Quartet, uma série deles...

JR: É mesmo? Nossa, eu não consigo imaginar isso... 
RM: Eram os feras da época... O Modern Jazz Quartet, "Receber a gente? Eles?”. “Sabe, quer ver? Vamos, sai aqui...”. Quando saímos já vieram abraçar a gente. Eu não acreditava, mas a nossa música já tinha ido antes da gente.

Então, foi mais ou menos isso. Acho que a Bossa Nova foi importante pra música brasileira, mas também pra música do Brasil lá fora.

JR: E quais compositores você considera suas maiores influências musicais?

RM: Do Brasil?

JR: Do Brasil e do exterior, mas principalmente do Brasil.

RM: Do Brasil, Tom Jobim sem dúvida. Aí tinha uma turma que vinha... Dick Farney, Tito Madi... Esses que eu me lembro. Aí Carlos Lyra, muito garoto ainda, mas já faziam as coisas. Já tinham alguma música gravada, entende? Era meio por aí, eu não vejo muito mais. A coisa veio muito do Jobim, a porta pra gente era o Jobim, e 246 uma música ou outra que você via. Tinha um cara que de repente fazia uma música que era interessante, mas faltava coisa da gente, porque o Jobim não podia fazer. Ele fez, sei lá, seiscentas, oitocentas músicas, mas no espaço da vida. Mas na época ele tinha, sei lá, cinquenta músicas, e não bastava pra gente, a gente precisava de mais, né? E começamos a fazer.

JR: E sobre Villa-Lobos, você chegou a conhecê-lo?

RM: Eu conheci Villa-Lobos um dia que o Jobim me chamou pra ir na casa dele: "Quer conhecer o Villa?". "Claro que eu quero". Aí, era interessante que ele (o Villa) tinha um concerto no Carnegie Hall, eu não sei quem convidou ele, e ele não queria fazer: "Não, muito chato esse negócio, tem que ir lá, tem que ensaiar, tem que...". Mas os caras mandaram uma vitrola, aquela que toca disco, os pezinhos palito, de presente. Aí ele aceitou fazer.

E aí o Tom falou: “Vai ter uma festa na casa do Villa-Lobos... Quer ir comigo?”. Eu disse: "Eu quero, claro, mas festa de quê?". Ele falou: “Também não sei, sei lá, festa de grã-fino, todo mundo dançando, tocando jazz e tal". Aí o Tom falou: [apontou com 
a cabeça, como que pedindo pra olhar para um certo lugar]. Lá, mais no canto, VillaLobos, com aquele paletó, aquele colete dele, cinza caindo pela roupa toda, e ele escrevendo a sinfonia, no meio...

JR: 0 que ele estava escrevendo?

RM: A tal sinfonia que era pro Estados Unidos, que eles contrataram. Eu não sei qual era...

JR: Não era Floresta do Amazonas?

RM: Eu não sei...

JR: Que ano foi isso?

RM: Isso foi... 1959. Aí eu falei: "Mas como é que ele está escrevendo isso?". E as mulheres dançando... [canta e imita dança e barulhos]. E o barulho...

JR: Ele já estava doente também, não é?

RM: Não sei, eu não sabia nada dele. Aí o Tom falou: "Vamos chegando...". Fomos chegando, e ele lá, nem olhava nada, ele escrevendo lá, e a gente ficou olhando aqui. Aí ficamos assim olhando ele escrever. Aí o Tom falou assim: "Impossível, como é que ele está escrevendo uma sinfonia, criando?". Daqui a pouco ele [Villa-Lobos]: “0 que vocês querem?". Ele era todo assim, né? [risos]. "Não, não, maestro, a gente está impressionado, você escrevendo..." "Impressionado por quê? Tô fazendo um trabalho aqui, que que...?". E ele não reconheceu o Tom, não reconheceu. Aí a gente: "Não, desculpe maestro, mas a gente fica impressionado, com esse barulho, essa coisa, o senhor escrevendo uma sinfonia assim, como é que pode?". "Que tem? 0 ouvido de dentro não tem nada que ver com o ouvido de fora..."

JR: Não acredito, você estava presente nisso? 
RM: Estava, eu e Tom. Depois eu soube que ele foi pro Carnegie Hall pra ensaiar a peça. Ele era grosso mesmo [risos]. Aí o pessoal falando: “Ó, maestro, tem umas pessoas, umas sete pessoas que querem falar com o senhor...". "O quê?". "Não sei, estão lá fora, mando entrar?”. "Não, deixa lá que eu vou lá fora”. Aí ele foi lá, e as pessoas: "Oi maestro, nós somos brasileiros, e sabendo que o senhor está aqui, queríamos convidá-lo pra uma feijoada". Aí ele falou: "Meu filho, eu não estou em idade de conhecer mais ninguém não, e não gosto de feijoada não..." [risos]. Maravilha isso, né? E os caras: "Não maestro, desculpe”, e foram embora [risos].

JR: E o Léo Peracchi, estava presente nesse contexto?

RM: Não. Eu conheci muito o Léo Peracchi. Aí já em gravadora, porque o Léo ficou muito amigo do Tom.

JR: Porque eu acho que foi por intermédio do Léo que o Tom conheceu o VillaLobos também...

RM: Ah, pode ser, aí eu não sei... Sei da obra do Villa-Lobos, tinha coisas da obra dele, mas não sei de mais histórias. Só sei das histórias que eu compartilhei ali, através do Tom. Quem eu conheci mais, depois, foi o Guerra-Peixe. Eu estudei com o Guerra. Eu estudei com duas pessoas: Moacir Santos também, logo que eu comecei, tinha dezoito anos.

O Moacir abraçou as coisas da gente: "Nossa, vocês fazem umas coisas legais, vamos ver, como é que é isso aí, como é que faz...?". E o Guerra também. O Guerra só achava a gente um pouco jazzista demais. 0 Moacir não, já entrou junto com a gente. O Moacir me ensinou muita coisa, nem falo de música, de vida! Me ensinou que fumar um cigarro só é melhor do que fumar os vinte que eu fumava na época [risos]. Mas um que eu espero vinte e quatro horas, sento nessa poltrona... [faz gestos como que fumando]". Ah! [risos]. Se você fuma vinte, perdeu a graça. Então, eu tive dois mestres bons.

JR: Você ouvia Villa-Lobos? 
RM: Ouvia porque o Tom gostava muito. Eu não ouvia por mim. É porque era uma festa a nossa vida, sabe? A gente só falava: "Hoje aonde é que é?". Nem perguntavam o que que era, nada. "Onde é que é hoje?". Porque todo dia a gente estava na casa de alguém.

JR: Eram reuniões? Também tocavam?

RM: Tudo.

Você imagina o seguinte: eu tinha uma namoradinha que tocava acordeom, e tocava mal pra caramba, uma coisa horrorosa. Mas ela um dia falou assim: "Eu vou ter a festa de fim de ano na minha escola no Copacabana Palace, você vai?". "Eu vou!". Peguei o terno, fui. Eram cinquenta meninas tocando acordeom, Cinquenta! Um acordeom já é duro, né? Cinquenta...? [imita o som de acordeom]. Eu falei pra ela: "Nossa, é impossível". Terminei o meu namoro ali na hora [risos], com acordeom não podia! Então, o que acontecia? Pra levar é pesado, pra mulher... Então, elas trocaram o acordeom pelo violão, de uma hora pra outra, todo mundo dizia: "Não, não quero mais o acordeom... Ah! O violão sim...". Levava aqui, e tal... [faz gestos de alguém carregando um violão]. Então a gente tinha muito trabalho, trabalho e diversão o tempo todo.

JR: E engraçado que agora, você me falando isso, eu penso: teve uma certa troca, porque o piano esteve na moda durante uma época. Depois houve essa troca pelo violão.

RM: Depois teve o acordeom porque o piano você não podia levar pra casa do outro, e o acordeom podia, mesmo pesado. Mas quando veio o violão, e com a batidinha do João Gilberto, então...

Era uma loucura o que se fazia de música. Eu vou te falar, na casa da Nara Leão, duzentas músicas foram feitas. Duzentas músicas foram feitas, sem medo de errar. A gente um dia começou: “Olha, essa aqui foi feita...”. A Leila Pinheiro me perguntando, e a gente: “Tá, tá', tá, tá, tá..." [faz gesto como se tivesse apontando pra uma lista]. "Puxa, mas tudo foi feito lá?”. Uma época foi, né? Eu por exemplo, não fazia ainda, era doido pra fazer, mas tinha pouco letrista. 
JR: Quem foi seu maior parceiro, o Ronaldo Bôscoli?

RM: Foi o Ronaldo Bôscoli, que fazia com o Carlinhos Lyra, toda noite uma música, toda! Aí o Carlinhos um dia não foi, e eu disse: “Opa, eu tenho...” [gestos como que tocando violão e risadas]. Ronaldo ficou uma fera que ele não foi e não avisou. Aí já fiz duas músicas com ele ali. Peguei, roubei o Ronaldo do Carlinhos né? E fiquei com ele.

JR: Seu professor de violão foi o Moacir então?

RM: Não. Eu estudei piano com o Moacir. Quer dizer, não piano, música, mas pelo piano. Ele dizia: "Harmoniza essa música...” [gestos tocando piano]. Aí escrevia ela toda, e o Moacir davas as dicas: “Quintas paralelas não é bom...”. O ano inteiro. Puxa, toda vez ele já falava: "Bom, agora é o exame de final do ano, não pode quintas paralelas". Eu dizia: "Tá bom". Fiquei, sabe, uma semana em casa, fiz uma peça, e falei: "Não tem nenhuma quinta paralela". Aí levei pra ele, ele tocou: "Tum tum tum" [faz gestos como se estivesse tocando piano]. "Parabéns, não tem nenhuma quinta paralela, aprendeu que não deve botar?". "Aprendi". "Então pode botar, agora que você aprendeu como deve, se precisar, pode”. Ai eu disse: “Que maravilha, né?” [risos]. Então eu estudei com ele harmonia, não foi instrumento. Mas aí um pouco pro piano. Já com o Guerra eu estudei mais orquestração, instrumentação.

JR: E você estudou canto orfeônico?

RM: Estudei, Maria Luiza Priolli [risos]. É o método até hoje, né? Estudei um bocado dela.

JR: Na escola?

RM: Estudei junto na mesma escola que eu estudava com o Guerra-Peixe. Era a PróArte, lá no Rio. Então a gente fazia canto orfeônico e fazia orquestração, instrumentação. 
JR: E na sua obra você vê influências de Villa?

RM: Acho que não, mas de algumas coisas que eu fiz as pessoas falam: "Tem Villa-Lobos aí, hein?".

JR: Mas você não parou pra pensar...

RM: É, porque eu não conheço o suficiente... O Edu Lobo já conheceu muito mais, ele foi muito mais por aí...

JR: Tom Jobim também, não é?

RM: O Tom Jobim também. O Tom estudou com os caras. Koellreutter, que era um músico muito bom. Mas eu não, eu fui meio daqui pra diante, entendeu? Eu pensei: “Ah, é daqui, vocês estão aqui? Eu vou daqui pra diante, né?" [risos]. E é engraçado porque o Tom uma vez me telefonou e falou assim: "Menésca, que que cê tá fazendo?". Era hora do almoço. Eu falei: “Tô indo pra tua casa, claro" [risos]. Aquilo pra mim é um convite sempre [risos]. É, eu nunca fui na casa dele invadir: "Tom, ôba”, mas: “Que que cê está fazendo?”, eu digo: “Tô indo pra tua casa!”. Ele falou: "Então vem pra cá porque eu fiz uma música tua”, e eu falei "Como é que é?". "Não, vem pra cá". Aí eu fui pensando: “Como é que ele fez uma música minha? O que quer dizer isso? Ele fez um arranjo de uma música minha, né? Ou ... Não sei...”. Aí cheguei lá e ele tocou uma música, e disse: "Chama-se Surfboard" [canta um trecho com onomatopeias]. Eu fiquei louco com a música, e falei: “Tom, eu estou gravando um disco, posso gravar tua música?”. "Claro, é tua” [risos]. "Agora me explica o que que é esse negócio de fez uma música minha", e ele falou: "Se eu não fizesse cê fazia essa, sabe, essa cê fazia”. Eu falei: “Mas, Tom, não...”. Ele falou... [cantarola o início de $O$ barquinho] sabe... ?"É um barquinho ao contrário aqui, né?”. Então ele queria dizer o seguinte, que eu tinha um estilo compôr, como Marcos Valle também [cantarola Samba de Verão], e vai mudando a coisa, mas tem uma célula que anda. E o Tom falava isso: "Vocês dois tem um negócio", e eu dizia: "Bacana". Então, a gente veio do passado, porque está tudo aqui, né? [apontando para a cabeça]. Mas não tinha 
consciência de coisas assim. Mas eu tenho umas quatro músicas que o pessoal gosta e diz: “Obaaa... Ó o Villa por aí...” [risos].

JR: E na Bossa Nova em geral, bem como na música brasileira, aonde você vê influências do Villa-Lobos?

RM: Olha, eu vi principalmente nisso... O Baden teve influência do Villa, quando ele vai pros temas mais na Bahia também, pois o Villa tinha umas coisas... Né? Do interiorzão... E o Tom teve muita influência do Villa. Tem aquelas músicas dele que não são, vamos dizer, as músicas que estouraram, mas são as músicas mais pesadas assim, tem muita coisa da Villa, ele mesmo falava.

O Matita Perê também, por ali você vê muito Villa. O Edu Lobo também teve muito. 0 que você pode falar do Toquinho que é Villa-Lobos, é intuitivamente.

JR: Mas talvez a gente possa pensar numa certa continuidade... 0 Villa veio antes e vocês continuaram com o Tom ... O que você acha sobre isso?

RM: Exato, mas uns sem saber, e uns sabendo... Que é o Tom. 0 Tom falava: "Olha, essa aqui é Villa-Lobos..." [fazendo gestos como se tocasse piano]. Então ele tinha consciência.

JR: Talvez isso tenha ajudado na construção dessa idéia de Brasil, que vocês continuaram através da Bossa Nova (que virou uma música brasileira internacional...). Então, talvez essa geração que começou no Villa e veio se desenvolvendo através da Bossa Nova...

RM: Foi empurrando a gente... Não tem dúvida! Você vê o chorinho, por exemplo, eu falo assim: eu tenho pena hoje de não ter entrado mais no choro, porque era a zona norte do Rio. De repente quando o choro voltou eu disse: "Puxa, que riqueza que é isso aqui!". E não é a minha formação, eu venho mais, muito mais do jazz, apesar de ter até uns dois chorinhos e tal. Agora, quem vem do choro, que vem lá daquele primeiro choro e tudo, você sente. Sei lá: Guinga, você olha e tem as coisas do choro, e tem Villa-Lobos... 
JR: E jazz também, não é?

RM: E tem jazz... A gente é resultante disso tudo. Eu não acredito numa pessoa que fala: “Não, eu parti daqui!". Não tem. Até o Lobão falou assim: “O rock bateu no muro, nós achamos que inventamos a coisa, mas não temos o passado do próprio rock". Tem que ter, tem que vir do Elvis Presley, tem que vir dos blueseiros. Pra você fazer o rock que se faz, o melhor rock, ele falou: "Nós batemos no muro" [risos].

JR: E você começou a estudar música com quem mesmo?

RM: Com o Moacir Santos...

JR: Ah, foi ele o seu primeiro professor?

RM: Foi o primeiro.

Eu tinha um ano de violão só, e fui tocar com a cantora Sylvinha Telles, que achou eu podia tocar legal. Ela me chamou pra fazer uma turnê com ela, e eu falei: "Não posso, eu tenho um ano de violão". "Mas deixa, calma, calma, deixa eu te explicar: estou grávida, daqui a três meses eu tenho filho, então vou ficar sem trabalhar três meses, e depois vou ficar mais três meses depois de ter o filho, então nós temos seis meses pra ensaiar", aí eu disse: "Então tá, né?". Aí passamos ensaiando, preparamos aquelas trinta músicas que a gente mexia aqui, mas ok. Aí fizemos a turnê, o primeiro trabalho que eu fiz, do Amazonas até o Rio, e chegamos no Rio. Aí ela falou assim: “Agora tem o seguinte...”. E eu aqui, já achando, né? [gestos de convencido]. Ela falou: “Não, agora vai estudar”. “Tá, tá, bacana, com quem?”, ela falou: "Eu vou te arranjar um professor". Aí ela falou com o Moacir e o Moacir me chamou pra estudar. Eu nem o conhecia, nem sabia quem era o Moacir.

JR: O Moacir foi uma peça chave nisso tudo...

RM: Puxa, super chave, e a gente trazia o Moacir pra casa da Nara, e ele ficava: “óh, que coisa, como é que é isso? Aí, bacana!". Sabe, ele valorizava algumas coisas. 
Então foi muito importante a presença dele ali. E o Guerra também, porque o Guerra, pra mim foi um pai. Eu fazia os arranjos de orquestra, e ele falava: "Escreve pra orquestra, escreve”. "Mas pra quê?”. "Não sei, escreve”. E na TV Tupi, na época, ele tinha a orquestra, então ensaiava a orquestra com as coisas e botava meus arranjos como se fosse ao ar... [sorrindo]. E ele ia no arranjo [gesto com que molhando a caneta na boca], escrevia, molhava assim óh [molhando a caneta novamente], escrevia um negocinho no meu arranjo e tal, e falava: "Vamos lá pro bar". E ia pro bar e falava: "Por que que fez isso?", e eu dizia "Por causa disso e disso". "Vou te mostrar como é que faz, exatamente o que você fez, mas de outra maneira um pouquinho diferente". Olha que genialidade, por exemplo...

JR: Você ainda compõe bastante?

RM: Bastante, bastante. Eu tenho feito muita coisa. 0 que acontece é que você não tem mais um mercado bom pra música nova. A rádio os caras não tocam, os discos não vendem e tal. Então eu gravo muito com o pessoal de fora, gravo muito.

254 A cantora Stacey Kent, por exemplo, que é uma maravilhosa de jazz, eu fui lá e gravei com ela agora.

Nos shows aqui as pessoas pedem sempre as mesmas músicas. Mas a gente põe outras. Por exemplo, a Leila vai cantar uma música nova minha. Até eu falei: "Leila não é, esse aqui é uma coisa da amostragem da Bossa como eu vendo". "Ah Menescal, não quero saber, tira isso, vamos tocar essa aqui que eu tô apaixonada por ela...". A Leila por exemplo chama de "menesquências" quando: "Eita, pintou uma menesquência aqui..." [risos], que era harmonia diferente e tal. Quer ver um exemplo? Deixa eu ver uma coisa aqui... [e procura um instrumento]. Não tem muitos instrumentos aqui, mas vou te mostrar: Manhã de carnaval [pega a guitarra]. Só um pedacinho dela aqui... [E começa a cantar e cantarolar, rearmonizando].

Essas coisas assim... Então, acho que a música ganha uma coisa nova e eu fico feliz em falar: "Que bom, posso mostrar ela de uma outra maneira".

JR: Você está sempre nos shows tocando de uma forma diferente as músicas? 
RM: Ah, sempre que puder eu estou inventando... "Menesquências..." [risos].

JR: Tudo escrito em arranjos?

RM: Tudo escrito. Eu escrevo tudo, estou cheio de arranjos por aí. Não sei aonde é que está mas está por aí. Está tudo as pastas ali. Os próprios músicos gostam: "Opa, bacana isso aquil".

Tudo na música é a harmonia. Na arquitetura você faz a base da casa. Mas aqui o cara fala: "Que bonito ficou isso!". É isso, quer dizer: sua visão que você acrescenta naquela base que está ali.

JR: E o Toninho Horta, você tem contato com ele?

RM: Tenho... Tive muito contato com ele. Até gravei muita coisa dele. Mas depois a vida separou, ele foi pro Estados Unidos, ficou morando lá, depois mora em Minas e tal. Mas de vez a gente se encontra e... [gestos como se tocasse guitarra].

Ele é danado nas harmonias, e o Guinga também.

JR: Essas rearmonizações você acha que vieram dos seus estudos com quem? Ou apenas de ouvir música?

RM: Eu não sei... Como o Caymmi falou: "Será que fui eu que fiz?" [risos]. Um dia eu perguntei: "Caymmi, você diz que faz cinco posições no violão, como é que você fez Canção da noiva?", e ele falou "Será que eu fiz?". "Não foi você?". "Não, veio a mim, eu mostrei".

JR: Você busca pela sonoridade? Ou alguma relação harmônica? Ou é o som que você procura?

RM: Não sei, me vem muito, me vem... Tem gente que sabe procurar, vai daqui, daqui eu vou pra ali... [gestos tocando violão]. Eu não, de repente vem uma frase, aí me dá uma agonia porque eu estou no carro, aí paro o carro pego aqui... [imita pegar o celular para gravar e cantarola]. Se você olhar meu iPhone está cheio 
de pedacinho. Aí sabe, vem... E eu digo: “Então essa aí tem que ir, tem que ir nela...”. Essa que a Leila vai cantar agora ficou legal, e o nome é bom: "Cai entre nós".

JR: Posso pedir pra você tocar? Tocar pra gente terminar?

RM: Pode... Mas isso aqui não tem som, né...? [toca a guitarra]. Sei lá, tem tanta coisa...

$$
[\ldots]
$$

Menescal então toca por uns três minutos enquanto comentamos e conversamos. Toca então uma rearmonização com nova letra para Atirei o pau no gato, improvisando também sobre a nova harmonia e comenta:

RM: Aí fica outra coisa, né? E aí eu mudei a letra, que eu não vou atirar o pau no gato de jeito nenhum! [e sorri].

Uma das frases com que ele termina a entrevista, falando sobre o momento musical e artístico atual: “Olha, nunca esteve tão bom!”. E por último: “A troca é 256 essencial".

JR - Seguimos conversando, até nos despedirmos. Posso dizer que a presente entrevista contribuiu imensamente para minha atual pesquisa acadêmica de doutorado em andamento, que procura analisar a influência e os pontos de conexão entre Villa-Lobos, Tom Jobim e a origem da Bossa Nova. Assim, tive a oportunidade de ter na minha frente um dos maiores nomes da Bossa Nova e da música brasileira, tão gentilmente conversando, respondendo às perguntas, tocando e cantando para mim, contando-me sua vida, suas histórias, as histórias da Bossa Nova e da música brasileira. Diversas vezes ainda Menescal descreveu seus vínculos e sua relação com Moacir Santos, Tom Jobim, Nara Leão, Guerra Peixe, dentre diversos outros grandes nomes da música brasileira.

Roberto Menescal reafirmou a influência de Villa-Lobos sobre Tom Jobim, sua manifestação no disco Matita Perê (de Jobim), e sobre outros compositores como Baden Powell e Edu Lobo. Esta entrevista também possibilitou conhecer o 
relato da visita de Menescal, juntamente com Tom Jobim, à casa de Villa-Lobos, quando ambos testemunharam um momento em que o compositor escrevia uma grade orquestral (provavelmente de Floresta do Amazonas). Eu já ouvira relatos em entrevistas gravadas do próprio Tom Jobim, mencionando uma visita a Villa-Lobos feita por volta de 1958, na qual Jobim diz ter visto o compositor escrevendo uma partitura orquestral "do piccolo ao contrabaixo"; agora, além de confirmar esta informação, que parece apontar com grande probabilidade para Floresta do Amazonas, também posso dizer que estive frente a frente com alguém que também presenciou aquele momento.

As informações obtidas nesta entrevista contribuem para estruturar contextualmente minha pesquisa e apontar caminhos para diferentes possibilidades analíticas, enriquecendo também as informações acerca da história da Bossa Nova (cujos 60 anos de surgimento podem ser celebrados também com esta entrevista, considerando como seu marco inicial o lançamento do disco Canção do amor demais de Elizete Cardoso em 1958) e da música brasileira, da qual Menescal foi parte vital de sua construção. Sem dúvida, um momento ímpar na minha vida pessoal, musical e acadêmica. 